\title{
Severe coronary artery disease after radiation therapy of the chest and mediastinum: clinical presentation and treatment
}

\author{
Fulvio Orzan, Antonio Brusca, Maria R Conte, Patrizia Presbitero, Maria C Figliomeni
}

\begin{abstract}
Objective-To define the clinical and angiographic features and the therapeutic problems in patients with coronary artery disease after therapeutic irradiation of the chest.

Design-An observational retrospective study.

Setting-The cardiac catheterisation laboratory, university medical school.

Patients-15 subjects (8 men and 7 women, aged 25-56 years, mean 44) examined in the cardiac catheterisation laboratory, who had significant coronary artery disease years after having radiation treatment to the chest and anterior mediastinum. In the early stages of the study angiography was performed because of typical symptoms of ischaemic heart disease. Later on it was performed because of a high index of suspicion in people with signs of extensive radiation heart damage.
\end{abstract}

Main outcome measures-Clinical and electrocardiographic evidence of ischaemic heart disease; echocardiographic signs of pericardial, myocardial or valvar involvement; angiographic evidence of coronary arterial stenosis, with special attention to the ostia; haemodynamic and angiographic signs of pericardial, myocardial, and valvar disease. Survival and symptomatic and functional status were ascertained after medical or surgical treatment.

Results-The patients were relatively young and had no risk factors. Seven patients had no signs or symptoms of ischaemic heart disease. Ten patients had ostial stenosis, which was associated with extensive involvement of other cardiac structures in nine of them. Seven required surgical treatment for coronary artery disease. Two died, one at surgery and the other one six months later. Five patients had complications associated with irradiation.

Conclusions-Coronary arterial disease can be reasonably ascribed to the effects of chest irradiation when the patients are young and free from risk factors, especially if the obstructions are ostial and there is important damage to other cardiac structures. In patients with damage to other cardiac structures angina and infarction are often absent and coronary angiography seems to be mandatory. Patients often require surgical treatment and postoperative complications are common.

(Br Heart f 1993;69:496-500)

Since the first comprehensive series reported by Cohn et al. ${ }^{1}$ cardiac involvement after $\dot{\sigma}$ chest and/or mediastinal radiation therapy $\vec{c}$ has been increasingly reported. Pericardial disease is the most frequent finding. ${ }^{2-4}$ Cardiomyopathy, ${ }^{5}$ valve disease, ${ }^{26}$ and disorders of the conduction tissue ${ }^{7}$ and of the coronary arteries have been described too. ${ }^{289}$ The incidence of coronary artery lesions, $\varnothing$ though difficult to calculate, has been estimated to be $6 \% .{ }^{10}$ Narrowing of the coronary ostia has also been reported. ${ }^{811-16} \mathrm{We}$ describe the findings in 15 patients with coronary artery disease after radiation therapy of the chest and mediastinum and review other relevant published reports.

\section{Patients and methods}

PATIENTS

Between 1985 and 1990, 24 patients who had received radiation treatment of the anterior chest and mediastinum, had coronary arteriography in our laboratory. Cardiac involve- of ment was suspected in all because of symptoms and/or clinical signs. Fifteen 운 patients (seven men and eight women, aged $\rightarrow$ 25-56) were found to have important coronary artery disease (table 1 ). Radiation treat- $N$ ment was given for Hodgkin's disease in eight patients, breast cancer in five, and lymphoma 옹 and seminoma in one patient each.

\section{CORONARY RISK FACTORS}

Patient 11 had smoked 20 cigarettes per day $\stackrel{\overparen{P}}{\rightarrow}$ for 20 years. Patient 8 had a serum choles- 0 terol of $250 \mathrm{mg} / \mathrm{dl}$. There were no traditional $\mathrm{O}^{\circ}$ risk factors in the remaining 11 patients. $\stackrel{\mathbb{D}}{\mathbb{D}}$

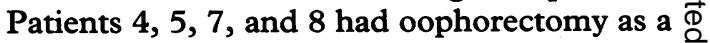
part of their treatment for breast cancer.

\section{RADIATION DOSE AND TECHNIQUE}

The interval between radiotherapy and onset of cardiac signs and symptoms ranged from $3 \stackrel{ }{\partial}$ to 28 years (mean 12). In eight patients (cases 1-3, 9-12, 15) a mantle field irradiation technique was used; patients 1 and 11 received an additional dose to the infrascapu- 
Table 1 Data on 15 patients with coronary artery disease after radiotherapy

\begin{tabular}{lllllll}
\hline $\begin{array}{l}\text { Patient } \\
\text { No }\end{array}$ & $\begin{array}{c}\text { Age } \\
(y r)\end{array}$ & Sex & CRF & $\begin{array}{c}\text { Latency } \\
(y r)\end{array}$ & $\begin{array}{l}\text { Dose } \\
(G y)\end{array}$ & Neoplasm \\
\hline 1 & 49 & M & - & 28 & 122 & Hodgkin \\
2 & 46 & F & - & 23 & 100 & Hodgkin \\
3 & 39 & F & - & 15 & 92 & Lymphoma \\
4 & 56 & F & - & 4 & 42 & Breast cancer \\
5 & 49 & F & - & 11 & 40 & Breast cancer \\
6 & 52 & M & - & 10 & 42 & Seminoma \\
7 & 51 & F & - & 3 & 40 & Breast cancer \\
8 & 56 & F & Chol & 6 & 45 & Breast cancer \\
9 & 41 & M & - & 13 & 42 & Hodgkin \\
10 & 40 & M & - & 12 & 45 & Hodgkin \\
11 & 43 & M & Smoke & 13 & 100 & Hodgkin \\
12 & 32 & M & - & 14 & 40 & Hodgkin \\
13 & 51 & F & - & 4 & 42 & Breast cancer \\
14 & 25 & F & - & 10 & 41 & Hodgkin \\
15 & 31 & M & - & 15 & 46 & Hodgkin \\
\hline
\end{tabular}

Chol, hypercholesterolaemia; CRF, coronary risk factors.

lar region, of $30 \mathrm{~Gy}$ and $55 \mathrm{~Gy}$, respectively. Cases $4,5,7,8,13$, and 15 received anterior field as well as supra and infra clavicular irradiation. The total radiation dose to the chest ranged from 40 to $122 \mathrm{~Gy}$. None of these patients had had deliberate cardiac shielding.

\section{CLINICAL EVALUATION}

Each patient had a routine prospective clinical examination performed by at least three of us, routine blood chemistry (including total and HDL cholesterol and triglycerides) chest $x$ ray, and a basal electrocardiogram. Cross sectional, $M$ mode, and Doppler echocardiography were performed in nine patients, and a treadmill exercise test in six.

\section{CARDIAC CATHETERISATION}

Coronary angiography was performed in all patients by Judkin's technique, and a biplane left ventriculogram was also obtained in the right and left anterior oblique projections. An ostial lesion was diagnosed on the basis of the following criteria: (a) a narrowing of at least $50 \%$ of the ostium on the cineradiogram; (b) no reflux of contrast into the aortic sinus; (c) a drop in the pressure recorded at the tip of the catheter; (d) failure of the contrast to be cleared from the injected artery until the tip of the catheter was withdrawn. Other

Table 2 Symptoms, signs, electrocardiogram, treadmill test

\begin{tabular}{|c|c|c|c|c|}
\hline Patient No & Symptoms & Signs & $E C G$ & Treadmill \\
\hline 1 & $\begin{array}{l}\text { Angina III, } \\
\text { dyspnoea }\end{array}$ & $\begin{array}{l}\text { Aortic stenosis } \\
\text { regurgitation }\end{array}$ & LBBB & \\
\hline 2 & Dyspnoea & Pericardial effusion & 3rd A-V block & \\
\hline 3 & Angina II & & & + \\
\hline 4 & Angina III & & & + \\
\hline 5 & Heart failure & $\begin{array}{l}\text { Constrictive pericarditis, } \\
\text { mitral/tricuspid } \\
\text { regurgitation }\end{array}$ & & \\
\hline 6 & Angina III & & & + \\
\hline 7 & Angina III & & & + \\
\hline 8 & Angina III & $\begin{array}{l}\text { Myocardial infarction, } \\
\text { mitral regurgitation }\end{array}$ & & + \\
\hline 9 & Angina I & & & + \\
\hline 10 & Heart failure & $\begin{array}{l}\text { Myocardial infarction, } \\
\text { pericardial effusion }\end{array}$ & & \\
\hline 11 & $\begin{array}{l}\text { Syncope, } \\
\text { angina I } \\
\text { dyspnoea }\end{array}$ & & 3rd A-V block & \\
\hline $\begin{array}{l}12 \\
13\end{array}$ & $\begin{array}{l}\text { Dyspnoea } \\
\text { Dyspnoea }\end{array}$ & $\begin{array}{l}\text { Constrictive pericarditis } \\
\text { Mitral stenosis/ } \\
\text { regurgitation }\end{array}$ & & \\
\hline 14 & $\begin{array}{l}\text { Pleural } \\
\text { effusion }\end{array}$ & $\begin{array}{l}\text { Mitral regurgitation } \\
\text { constrictive pericarditis }\end{array}$ & LBBB & \\
\hline 15 & Weakness & & 3rd A-V block & \\
\hline
\end{tabular}

ECG, electrocardiogram; LBBB, left bundle branch block; 3rd A-V block, third-degree atrioventricular block. coronary lesions were regarded as important if visual assessment showed a reduction of at least $70 \%$ in lumen diameter. Supravalvar aortography was performed in 10 cases. A pericardial constriction was diagnosed when the diastolic pressures of the left ventricle, right atrium, right ventricle, and pulmonary artery were higher than $15 \mathrm{~mm} \mathrm{Hg}$ and were within $5 \mathrm{~mm} \mathrm{Hg}$ of each other. An intracavitary electrophysiological study by the Scherlag technique ${ }^{17}$ was performed in three patients.

\section{Results}

CLINICAL PRESENTATION (TABLE 2)

There was clinical evidence of coronary artery disease in eight patients. Seven had angina on effort or at rest and one had angina after a myocardial infarction. Another patient was in heart failure after having had an infarction. Four patients were admitted with congestive heart failure and three with symptoms of chronic third degree atrioventricular block.

Pericardial constriction or effusion was diagnosed in five patients and valve disease in 10 on clinical grounds.

\section{CARDIAC CATHETERISATION/CORONARY ANGIOGRAPHY (TABLE 3) \\ Ostial lesions}

Ten patients had obstructive disease of the right or the left or both coronary ostia. The right coronary artery ostium was narrowed in seven cases. Left main ostial lesions were found in seven patients. These were critical in six and non critical in case 13. There were important concomitant lesions of major epicardial arteries in four.

Both ostia were affected in four of the 10 cases. Nine of these 10 patients also had valve lesions. There was always mitral valve regurgitation, either alone or with aortic disease. There was a definite rheumatic aetiology in only one case. Haemodynamic results indicated constrictive pericarditis in five cases. The size of the left ventricle was normal in all. The left ventricular ejection fraction was $>50 \%$ in all but one patient.

\section{Non-ostial disease}

Of the remaining five patients with no ostial narrowing, two had triple vessel disease. One subject had two vessel disease and one patient had single vessel disease. Three patients had mitral regurgitation; aortic regurgitation was also found in the two patients in whom an aortogram was obtained. There were no haemodynamic signs of pericardial constriction.

\section{TREATMENT (TABLE 4)}

Eight patients had cardiac surgery: in four of them revascularisation was the only procedure. Patient 3 had a left internal mammary artery grafted onto the left anterior descending coronary artery; immediately after surgery she had electrocardiographic changes typical of acute anterior ischaemia and was taken back to the operating room. The mammary artery was found to be occluded and was 
Table 3 Angiographic and haemodynamic findings

\begin{tabular}{|c|c|c|c|c|c|c|c|c|c|}
\hline Patient No & $L M$ & $R C A$ & Other & $L V E F$ & $M R$ & $A R$ & $A S$ & $T R$ & $C P$ \\
\hline 1 & + & + & $\begin{array}{l}\text { LAD, } \\
\text { (CX, RCA) }\end{array}$ & 0.58 & $2+$ & $1+$ & 35 & & - \\
\hline 2 & + & + & (LAD) & 0.54 & $1+$ & + & & & - \\
\hline 3 & + & + & $\begin{array}{l}\text { RCA, OM, } \\
\text { LAD, CX }\end{array}$ & $0 \cdot 71$ & $2+$ & ND & & & - \\
\hline 4 & + & - & (LAD, RCA) & 0.73 & - & - & & & - \\
\hline 5 & - & + & $\begin{array}{l}\text { RCA, } \\
(\mathrm{LAD}, \mathrm{CX}, \mathrm{OM})\end{array}$ & 0.57 & $2+$ & $1+$ & & $4+$ & + \\
\hline 6 & - & - & Ramus (CX) & 0.73 & - & ND & & & - \\
\hline 7 & - & - & (CX) & 0.68 & - & ND & & & - \\
\hline 8 & - & - & LAD, CX, RCA & 0.60 & $4+$ & $1+$ & & & - \\
\hline 9 & - & - & $\begin{array}{l}\mathrm{LAD}, \mathrm{DG}, \mathrm{RCA} \text {, } \\
(\mathrm{CX})\end{array}$ & 0.61 & $1+$ & ND & & & - \\
\hline 10 & - & + & (CX, MO, LAD) & 0.55 & $1+$ & ND & & & + \\
\hline 11 & - & - & RCA, (LAD, OM) & 0.52 & $1+$ & $2+$ & & & - \\
\hline 12 & + & + & CX, (RCA) & 0.52 & $2+$ & +- & & & + \\
\hline 13 & $(+)$ & - & (LAD, RCA, OM) & 0.36 & $2+$ & $1+$ & & $4+$ & - \\
\hline 14 & + & - & & 0.61 & $3+$ & +- & & +- & + \\
\hline 15 & - & + & (LAD) & 0.71 & $1+$ & $1+$ & & & + \\
\hline
\end{tabular}

$\mathrm{AR}$, aortic regurgitation; AS, aortic stenosis; CX, circumflex; CP, constrictive pericarditis; DG, diagonal; LAD, left anterior descending; LM, left main; LVEF, left ventricular ejection fraction; MR, mitral regurgitation; ND, not done; OM, obtuse $O$ marginal; RCA, right coronary artery; $T R$, tricuspid regurgitation.

marginal; RCA, right coronary artery; TR, tric
Non-critical lesions are shown in parentheses.

replaced by a saphenous vein graft. Patient 4 had a plastic reconstruction of the left main ostium.

Patient 7 had percutaneous dilatation of the stenotic left anterior descending coronary artery. Four patients had either a valve replacement or repair: a revascularisation procedure was carried out in three of them. In three additional patients the pericardium was resected. Patient 10 had pericardial drainage. Three patients required a permanent pacemaker implantation. Only three patients were not operated upon.

\section{SURGICAL COMPLICATIONS (TABLE 4)}

Two of the eight patients who had operations had a sternal dehiscence and recurrent pleural effusions. In patient 3, as already mentioned, the left internal mammary artery graft had to be replaced by a saphenous vein graft. Patient 14, a 25 year old woman, died in congestive heart failure on the $23 \mathrm{rd}$ postoperative day, from what retrospectively seemed to be restrictive cardiomyopathy.
FOLLOW UP (TABLE 4)

The follow up period ranged from three to 59 months. Patient 2 had recurrent pleural $\&$ effusions and died from the sequelae of post- $\frac{}{2}$ operative mediastinitis six months after her operation. Patient 1 was free of angina $50 £$ months after the operation, but had late $\overparen{\varnothing}$ bacterial endocarditis of the pulmonary valve $\vec{\bullet}$ with moderate regurgitation and congestive $\stackrel{\oplus}{\oplus}$ heart failure; he also needed a pacemaker implantation because of a bradycardiatachycardia syndrome. Of the five other patients who had operations four were symptom free 6-27 months after operation, but $\frac{\varnothing}{\varnothing}$ patient 5 had a refractory congestive failure $\stackrel{\varrho}{\Rightarrow}$ three years after operation caused by restric- $\frac{O}{3}$ tive myopathy diagnosed at a postoperative $\frac{}{\sigma}$ cardiac catheterisation and biopsy. She is awaiting a heart transplant. Patient 4 developed a $50 \%$ stenosis of the left anterior descending coronary artery. This vessel was? free from disease before her left main coro- $\frac{3}{3}$ nary artery was reconstructed. The patient who had percutaneous angioplasty had a bout

Table 4 Treatment and follow up

\begin{tabular}{|c|c|c|c|c|}
\hline \multirow{2}{*}{$\begin{array}{l}\text { Patient } \\
\text { No }\end{array}$} & \multirow[b]{2}{*}{ Treatment } & \multicolumn{2}{|l|}{ Complications } & \multirow{2}{*}{$\begin{array}{l}\text { Follow up } \\
\text { (mnth) }\end{array}$} \\
\hline & & Early & Late & \\
\hline 1 & $\begin{array}{l}\text { AVR, LIMA-LAD, RIMA-RCA, } \\
\text { VG-OM }\end{array}$ & $\begin{array}{l}\text { Mediastinitis, } \\
\text { sternal dehiscence }\end{array}$ & $\begin{array}{l}\text { SBE pulmonary valve, } \\
\text { M reg, brady-tachy, pacemaker }\end{array}$ & $\begin{array}{l}50, \\
\text { CHF NYHA II, }\end{array}$ \\
\hline 2 & VG-LAD & $\begin{array}{l}\text { Mediastinitis, } \\
\text { sternal dehiscence }\end{array}$ & & 6, Died \\
\hline 3 & VG-RCA, LIMA-LAD & $\begin{array}{l}\text { AMI, LIMA redo, } \\
\text { VG-LAD }\end{array}$ & & $23, \operatorname{CCS} 0$ \\
\hline $\begin{array}{r}4 \\
5 \\
6 \\
7 \\
8 \\
9 \\
10 \\
11 \\
12\end{array}$ & $\begin{array}{l}\text { LM ostial reconstruction } \\
\text { MVR, TV repair, pericardiectomy } \\
\text { Medical } \\
\text { PTCA of LAD } \\
\text { Medical } \\
\text { LMA-LAD } \\
\text { Medical and pericardial drainage } \\
\text { Medical-pacemaker } \\
\text { MV repair, pericardiectomy } \\
\text { LIMA-LAD, VG-OM, RCA }\end{array}$ & & $\begin{array}{l}\text { Stenosis LAD } 50 \% \\
\text { CHF, restrictive myopathy }\end{array}$ & $\begin{array}{l}\text { 27, CCS } 0 \\
59, \text { NYHA IV } \\
12, \text { CCS } 0 \\
12, \text { CCS } 0 \\
50, \text { CCS } 0 \\
27, \text { CCS } 0 \\
7 \text {, CCS } 0 \\
6, \text { CCS } 0, \text { NYHA } 0\end{array}$ \\
\hline $\begin{array}{l}13 \\
14\end{array}$ & $\begin{array}{l}\text { Medical } \\
\text { MV repair, pericardiectomy }\end{array}$ & & & $5, \operatorname{CCS} 0$ \\
\hline 15 & $\begin{array}{l}\text { LIMA-LAD, VG-OM } \\
\text { Medical-pacemaker }\end{array}$ & Died at surgery & & $3, \operatorname{CCS} 0$ \\
\hline
\end{tabular}

AMI, acute myocardial infarction; AVR, aortic valve replacement; brady-tachy, bradycardia-tachycardia syndrome; CCS, Canadian Cardiovascular Society grading of angina; CHF, congestive heart failure; LAD, left anterior descending; LIMA, left Canadian Cardiovascular Society grading of angina; CHF, congestive heart failure; LAD, left anterior descending; LIMA, left
internal mammary artery; LM, left main; MVR, mitral valve replacement; M reg, mitral regurgitation; OM, obtuse marginal; internal mammary artery; LM, left main; MVR, mitral valve replacement; $M$ reg, mitral regurgitation; OM, obtuse marginal;
PTCA, percutaneous transluminal coronary angioplasty; RCA, right coronary artery; RIMA, right internal mammary artery; SBE, subacute bacterial endocarditis; VG, vein graft. 
of chest pain a month after the procedure, but repeat coronary angiography showed a good result. The patients who did not have operations are free of angina.

\section{Discussion}

INCIDENCE AND MECHANISM OF CORONARY ARTERY DISEASE AFTER THERAPEUTIC IRRADIATION

The heart is not as resistant to radiation as has been suggested. The pericardium is most commonly damaged, but cardiac valves, coronary arteries, myocardium, and specific conduction tissue can be affected too. ${ }^{2-4} 8$

It is not known how often radiotherapy of the chest and mediastinum lead to cardiac lesions. Gottdiener et al found cardiac symptoms in $4 \%$ of 25 patients recalled 5-15 years after radiation therapy for Hodgkin's disease, echocardiographic evidence of pericardial effusion in $36 \%$, and an abnormal exercise ejection fraction (by radionuclide angiography) in $38 \% .^{18}$

Echocardiography, gated radionuclide ventriculography, and cardiac catheterisation showed cardiac disease in $96 \%$ of 48 irradiated patients studied at the University of Maryland Hospital. ${ }^{3}$ Fifteen had been referred for evaluation of specific cardiac symptoms and signs and 22 of the remaining 33 patients also had symptoms. More recently, Piovaccari et al found evidence of cardiac disease in only $11(10 \%)$ of 108 patients examined 14 years after radiotherapy for Hodgkin's disease. ${ }^{19}$

In the only true prospective study Boivin $e t$ $a l$, found that the relative death rate for coronary heart disease in patients irradiated for Hodgkin's disease was 1.5 , which is not significantly different from $1 .^{20}$ It is difficult to ascertain the incidence of coronary arterial involvement because coronary arteriography cannot be performed routinely.

Fajardo emphasised the difficulty of proving the causative role of $x$ ray therapy, which perhaps may only accelerate the development of coronary artery disease in patients who already have traditional risk factors. ${ }^{21}$ However, in some of the reported cases the histological appearance of the radiation induced lesions is different from that of typical atherosclerotic plaque: there is diffuse fibrosis of all the wall layers, with loss of smooth myocytes in the media and lipid deposits are scarce. ${ }^{2915}$

The early age at which coronary arterial stenoses develop and the absence of the common coronary risk factors also militate against a role for the common coronary risk factors. ${ }^{21516}$

\section{CORONARY OSTIAL STENOSES}

Another peculiar feature of post-radiation coronary artery disease in our patient was the high incidence of ostial lesions. In ten of our 15 patients there was narrowing of either the right or the left ostium or both ostia. In contrast, we found only 14 cases $(0.4 \%)$ of ostial stenosis in a series of 3314 non-irradiated patients with obstructive coronary artery disease studied in our laboratory between 1986 and 1990.

\section{INVOLVEMENT OF OTHER CARDIAC}

\section{STRUCTURES}

Coronary artery disease in irradiated patients is often associated with pericardial, valvar, and myocardial lesions, ${ }^{28922}$ and we found that nine of our 10 patients with ostial stenoses also had other clinically important cardiac lesions. Only one of them, patient 13, had had rheumatic fever.

In the five patients without ostial stenosis, the other cardiac structures were mostly spared by radiation damage, except for one case of complete atrioventricular block. Valvar disease was also less severe than in the patients with ostial lesions, except for patient eight, who had severe mitral regurgitation caused by an inferior myocardial infarction. Obviously, more subtle signs of cardiac involvement can be missed at cardiac catheterisation. Moreover, not all the valves were routinely explored, especially when there was no clinical evidence of valve disease. Six patients were not examined by aortography and the function of the tricuspid valve was studied only twice. Echocardiography can be very helpful for this. ${ }^{323}$

\section{CLINICAL PRESENTATION}

Despite important coronary involvement six of our patients did not have angina or myocardial infarction. Five of these subjects had a significant ostial lesion and symptoms and signs were caused by severe concomitant disease of the pericardium, valves, or conduction tissue.

The value of the commonly used non-invasive tests for myocardial ischaemia in these patients is not known, but we suspect that it is low because of the associated cardiac lesions. We recommend therefore that coronary arteriography be routinely performed and ostial lesions carefully sought in patients with obvious signs of post-radiation heart disease who have cardiac catheterisation. The patency of the internal mammary artery should also be verified.

In symptomfree patients without evidence of concomitant heart lesions, the incidence of coronary artery disease seems to be low. ${ }^{20}$ In such patients radiotherapy should be regarded as a coronary risk factor and a regular non-invasive follow up is advisable.

\section{DOSE/EFFECT RELATION}

Most of our patients received 40-45 Gy, which is generally regarded as standard in such cases. Of the four patients that received substantially higher doses, three had ostial disease. Despite the normal dose, seven of the remaining 11 patients had ostial lesions too. However, five of them were followed up for $>10$ years (table 1 ).

Thus eight of the 10 patients with ostial lesions had either received a high dose or had a follow up of $>10$ years or both. Conversely, an ostial stenosis was found in eight of 11 
patients who had either received a high dose or had a long follow up. We are now particularly suspicious of damage in patients who have received more than $40-45$ Gy or have been followed up for more than 10 years radiotherapy.

Protection of healthy tissues, including the heart, is a matter of great concern among radiotherapists. Several technical improvements have been proposed for radiotherapy of Hodgkin's disease, such as subcarinal block for better shielding, lower doses (35-40 instead of 40-45 Gy), hyperfractionation, and predictive assays of the radiation response. ${ }^{24}$ It has been proposed that the internal mammary nodes should not be routinely irradiated in patients with ductal carcinoma in situ of the breast. ${ }^{25}$

\section{TREATMENT}

The treatment of coronary arterial stenosis after thoracic irradiation has been described. Since the first report in 1976 by Ali et al, ${ }^{26}$ others $^{389141527-29}$ have used saphenous vein graft bypass surgery in their patients. The left internal mammary artery has rarely been used. ${ }^{29}$ It was found to be reduced to a fibrotic thread at surgery by Iqbal et $a .^{28}$ Hanet et $a l^{30}$ used percutaneous coronary angioplasty in their patient in whom angiography showed occlusion of the left internal mammary artery. Moreover, a group from the Cleveland Clinic reported that planned surgical revascularisation had to be abandoned in two of 15 patients because of severe mediastinal fibrosis. ${ }^{8}$

In two of our patients post-radiation damage to the skin and subcutaneous tissue impaired wound healing after operation. They had received the highest dose among those operated on. Such a complication seems to be rare; we found only one other published report of a similar case. ${ }^{31}$ This patient had received 42 Gy plus an additional dose of 25 Gy two years later, and developed radiodermatitis over the upper sternal region, as did patient 1 in our series.

Percutaneous transluminal coronary angioplasty was first used by Nakhjavan et $a l^{12}$ to treat a right ostial lesion, and subsequently used by others. ${ }^{8032}$ However, Handler et al reported on a patient who sustained an inferior myocardial infarction two months after successful angioplasty of the right coronary ostium. ${ }^{16}$ It can be difficult to use the internal mammary artery for emergency surgery.

What little evidence there is suggests that when revascularisation is indicated, a percutaneous angioplasty should be considered first for non-ostial lesions. Those with ostial stenosis should have surgery, despite the increased risk.

In patients with radiation-induced coronary artery disease wound healing may be impaired and little is known about how initially minor valve abnormalities develop. Restrictive myopathy can develop after pericardiectomy as we (cases 5 and 14) and others $^{363334}$ found. Heart block and severe pericardial effusion can develop years after radiotherapy.
1 Cohn KE, Stewart JR, Fajardo LF, Hancock EW. Heart disease following radiation. Medicine 1967;46:281-98

2 Brosius FC, Waller BF, Roberts WC. Radiation heart disease. Analysis of 16 young (aged 15 to 33 years) necropsy patients who received over 3500 rads to the heart. Am $\mathcal{F}$ Med 1981;70:519-30.

3 Applefeld MM, Wiernik PH. Cardiac disease after radiation therapy for Hodgkin's disease: Analysis of 48 patients. Am f Cardiol 1983;51:1679-81.

4 Stewart JR, Fajardo LF. Radiation-induced heart disease: an update. Prog Cardiovasc Dis 1984;27:173-94.

5 Burns RJ, Bar-Shlomo B, Druck MN, et al. Detection of radiation cardiomyopathy by gated radionuclide angiography. Am f Med 1983;74:297-302.

6 Warda M, Khan A, Massumi A, Mathur V, Klima T, Hall RJ. Radiation-induced valvular dysfunction. $\mathcal{f} \mathrm{Am} \mathrm{Col}$ Cardiol 1983;2:180-5.

7 Ebagosti A, Gueunoun M, Favre R, et al. Bloc auriculoventriculaire, complication de la radiothérapie du médiastin. Arch Mal Coeur 1989;82:935-9.

8 McEniery PT, Dorosti K, Schiavone WA, Pedrick TJ, Sheldon WC. Clinical and angiographic features of coronary artery disease after chest irradiation. $A m \mathcal{F}$ Cardiol 1987;60:1020-4.

9 Dunsmore LD, LoPonte MA, Dunsmore RA. Radiationinduced coronary artery disease. $\mathcal{F}$ Am Coll Cardiol 1986; 8:239-44.

10 Vacheron A, Heulin A, Metzger JPh, et al. Complications cardiaques de la radiothérapie. Ann Cardiol Angéiol 1983;32:465-72.

11 Salem BI, Terasawa M, Mathur VS, Garcia E, de Castro CM, Hall RJ. Left main coronary artery ostial stenosis: clinical markers, angiographic recognition and distinction from left main disease. Cathet Cardiovasc Diagn 1979;5:124-34.

12 Nakhjavan FK, Yazdanfar S, Friedman A. Percutaneous transluminal coronary angioplasty for stenosis of the stium of the right coronary artery after irradiation for Hodgkin's disease. Am $\mathcal{F}$ Cardiol 1984;53:341-2.

13 Stegaru-Hellring B, Keller $\mathrm{H}$, Bode $\mathrm{H}$, Usadel $\mathrm{K}-\mathrm{H}$ Wallwork J. Ostiumstenose beider Koronararterien und latente Hypothyreose als Folge der Strahlentherapie bei Morbus Hodgkin. Z Kardiol 1985;74:485-8.

14 Deloche A, Bellin J, Hennetier J, Carpentier A. Sténose ostiale coronaire post-radique (?) traitée par endartériectomie ostiale bilaterale. Presse Med 1987;16:780-1.

15 Grollier G, Commeau P, Mercier V, et al. Postradiotherapeutic left main coronary ostial stenosis: clinical and histological study. Eur Heart $\mathcal{f} 1988$; 9:567-70.

16 Handler CE, Livesey S, Lawton PA Coronary ostial tenosis after radiotherapy: angioplasty or coronary stenosis after radiotherapy: angioplasty

17 Scherlag BJ, Lau SH, Helfant RH, Berkowitz WD, Stein E, Damato AN. Catheter technique for recording His bundle activity in man. Circulation 1969;39:13-8.

18 Gottdiener JS, Katin MJ, Borer JS, Bacharach SL, Green MV. Late cardiac effects of therapeutic mediastinal irradiation. $N$ Engl f Med 1983;308:569-72.

19 Piovaccari G, Ferretti RM, Traini AM, et al. Pericardial and coronary artery disease after chest irradiation for Hodgkin's disease. Eur Heart f 1992;13(Suppl): 175.

20 Boivin J-F, Hutchison GB. Coronary heart disease mortality after irradiation for Hodkin's disease. Cancer ity after irradiatio

21 Fajardo I.F. Radiation-induced coronary artery disease Chest 1977; 5:563-4.

22 Toetterman KJ, Pesonen E, Siltanen P. Radiation-related chronic heart disease. Chest 1983;83:875-8.

23 Perrault DJ, Levy M, Herman JD, et al. Echocardiographic abnormalities following cardiac radiation. f Clin Oncol 1985;3:546-51.

24 Withers HR. Biological basis of radiation therapy for cancer. Lancet 1992;339:156-9.

25 Recht A. Radiotherapy and ductal carcinoma-in-situ of the breast. Lancet 1992;340:312.

26 Ali MK, Khalil KG, Fuller LM, et al. Radiation-related myocardial injury. Management of two cases. Cancer 1976;38:1941-6.

27 Annest LS, Anderson RP, Wei-i L, Hafermann MD. Coronary artery disease following mediastinal radiation therapy. ₹ Thorac Cardiovasc Surg 1983;85:257-63.

28 Iqbal SM, Hanson EL, Gensini GG. Bypass graft for coronary arterial stenosis following radiation therapy. Chest 1977;71:664-6.

29 Tenet W, Missri J, Hager D. Radiation-induced stenosis of the left main coronary artery. Cath Cardiovasc Diagn 1986;12:169-71.

30 Hanet C, Marchand E, Keyeux A. Left internal mammary artery occulusion after mastectomy and radiotherapy. Am ₹ Cardiol 1990;65:1044-5.

31 Velebit V, von Segesser L, Gabathuler J, Jornod J, Faidutti B. Right ventricular outflow obstruction after radiation therapy. I Thorac Cardiovasc Surg 1986;92:153-61.

32 Sande LM, Casariego J, Llorian AR. Percutaneous transluminal coronary angioplasty for coronary stenosis ransluminal coronary angioplasty for coronary stenosis

33 Botti RE, Driscol TE, Pearson OH, Smith JC. Radiation myocardial fibrosis simulating constrictive pericarditis. A review of the literature and a case report. Cancer 1968;22:1254-61.

34 Simon EB, Ling J, Mendizabal RC, Midwall RJ. Radiation-induced coronary artery disease. Am Heart $\dot{f}$ 1984;108:1032-4. 